Statistics, Actuarial Science, Economics ; V, Mathematical Physics and Applied Mathematics; VI, Logic and Philosophy ; VII, History and Education. The official languages of the Congress will be English, French, German, Italian and Russian. Harvard University has offered the use of its dormitories and dining-rooms for mathematicians and their guests for the period of the Congress, and the Organising Committee hopes that it will be possible to furmish board and room without charge to all mathematicians from outside the North American continent who are members of the Congress. Congress membership fees will be announced well in advance of the opening of the Congress. Every effort will be made to facilitate the travel at reasonable cost of foreign participants while in the United States. Communications about the Congress should be addressed to the American Mathematical Society, 531 West 116th Street, New York City 27, U.S.A.

\section{Congress of Comparative Pathology}

The International Congress of Comparative Pathology will hold its fifth meeting in Istanbul during May 17-20, 1949. The Congress covers all aspects of human, plant and veterinary pathology, and considerable latitude is permitted in the choice of subjects for discussion. The British National Committee (chairman, Prof. T. Dalling, Ministry of Agriculture) will be glad to receive, as soon as possible, the titles of communications which members in Great Britain, who hope to attend the Congress, wish to submit for transmission to the Secretaire Générale of the Permanent Committee. Further information can be obtained from Mr. R. E. Glover (honorary secretary, British National Committee), Royal Veterinary College, London, N.W.1, or from Pr. N. R. Belger, Taksim, Siraserviler 75/3, Istanbul.

\section{Commonwealth Fund Fellowships}

THE Commonwealth Fund of New York is offering in 1949 a number of fellowships for British subjects to study in the United States for one year. Twenty such fellowships will be available to British subjects between twenty-three and thirty-five years of age, who are graduates of a university of the United Kingdom or who have studied in one, having previously graduated from a university of Australia, New Zealand or South Africa. In addition there are three fellowships for candidates holding permanent positions in the higher ranks of the Civil Service of Great Britain, and five more fellowships for those in Government service in the Commonwealth. The emolument consists of a total grant of approximately 950 dollars with an allowance of 200 dollars a month plus free travel to and from the United States. Applications must be submitted by February 1, 1949, and full details may be obtained from the Secretary of the Committee of Award, 35 Portman Square, London, W.1.

\section{Royal Meteorological Society: Popular Lectures}

THE Royal Meteorological Society has arranged a series of monthly meetings, to be held at the Science Museum Lecture Theatre, Exhibition Road, South Kensington, and visitors will be welcome. The first meeting, on December 3 at 5.30 p.m., will consist of a film show, and thereafter popular lectures will be delivered at 6 p.m. by the following speakers on the dates shown: Sir George Simpson, January 12; Sir Nelson Johnson, February 10; Prof. Gordon
Manley, March 3 ; Dr. G. M. B. Dobson, April 6; Mr. E. Gold, May 5.

\section{University of London: Appointments}

THe following appointments in the University of London have been announced. Dr. Dennis Gabor has been appointed to the Mullard readership in elec. tronics tenable at the Imperial College of Science and Technology, London, as from Januạry 1, 1949. The title of reader in the University has been conferred on the following: Dr. Vera Fretter, lecturer in zoology at Birkbeck Collegə; Dr. P. A. I. Gorer, of the Department of Experimental Pathology, Guy's Hospital Medical School ; Dr. G. E. Newell, lecturer in zoology at Queen Mary College.

The degree of D.Sc. has been conferred on Mr. E. J. Popham, an external student.

\section{The Night Sky in December}

Fuxl moon occurs on Dec. 16d. 09h. 11m. U.T., and new moon on Dec. $30 \mathrm{~d} .09 \mathrm{~h} .44 \mathrm{~m}$. The following conjunctions with the moon take place: Dec. 2d. $16 \mathrm{~h}$., Jupiter $4^{\circ}$ N.; Dec. 2d. 17h., Mars $3^{\circ}$ N. ; Dec. 21d. $09 \mathrm{~h}$., Saturn $3^{\circ}$ S.; Dec. 28 d. $06 \mathrm{~h}$., Venus $4^{\circ}$ N. ; Dec. 31d. 19h., Mars $4^{\circ} \mathrm{N}$. In addition to these conjunctions with the moon, Mars is in conjunction with Jupiter on Dec. ld. 08h., Mars $1 \cdot 1^{\circ} \mathrm{S}$. Mercury rises at $7 \mathrm{~h}$. $15 \mathrm{~m}$. on Dec. 1 , or nearly half an hour before sunrise, but is too close to the sun for observation, and is not favourably placed for observation during the month. Venus is a morning star, rising at $4 \mathrm{~h} .40 \mathrm{~m} ., 5 \mathrm{~h} .23 \mathrm{~m}$. and $6 \mathrm{~h} .09 \mathrm{~m}$. at the beginning, middle and end of the month, respectively. The magnitude of the planet is $-\mathbf{3} \cdot 4$ during December, and the visible portion of the illuminated disk varies from 0.84 to 0.90 . Mars is still too close to the sun for favourable observation, setting less than an hour and a half after the sun throughout the month. Jupiter is also too close to the sun to be well observed, and is in conjunction with the sun on Jan. 1. Saturn, in the constellation of Leo, rises about $23 \mathrm{~h}$. on Dec. 1 and 21 . on Dec. 31 ; it is visible throughout the morning hours in the early part of the month and also during the later hours of the night in the last part of the month. The planet is stationary on Dec. 17. No oceultations of stars brighter than magnitude 6 take place during December. Winter solstice occurs on Dec. 21d. 23h.

\section{Announcements}

DR. W. CAMPBELL SMITH, keeper of the Department of Mineralogy in the British Museum (Natural History), has been appointed to the new post of deputy chief scientific officer in the Museum; he will retain his post in the Department of Mineralogy. Dr. Maurice Burton has been appointed a senior principal scientific officer (deputy keeper) in the Department of Zoology.

THe following appointments have been made in the University of Leods: Mr. W. J. Thomas, as lecturer in agricultural economics; Dr. A. D. Walsh, as lecturer in inorganic and physical chemistry.

THe following have been appointed officers of the Society for Visiting Scientists, 5 Burlington Street, London, W.1: President and Chairman, Sir Harold Spencer Jones ; Secretary, Prof. F. J. M. Stratton; Treasurer, Mr. H. R. Walters. 